\title{
Preparation and Evaluation of Sustained Release Matrix Tablets of Tolterodine Tartrate Using Guggul Resin
}

\author{
K. Latha, T. Chinni Kranthi and Naseeb Basha Shaik \\ Department of Pharmaceutics, G. Pulla Reddy College of Pharmacy, Mehdipatnam, \\ Hyderabad, Telangana, India-28.
}

(Received: September 10, 2017; Accepted: November 26, 2017; Published: January 30, 2018)

\begin{abstract}
The present study is based on preparation of sustained release matrix tablets of tolterodine tartrate (for overactive bladder treatment) using guggul resin. Tolterodine tartrate is a highly soluble drug, to increase the duration of action the release of the drug has to be sustained. Natural resin is used as a polymer to sustain the release of drug, which was isolated from guggul gum by petroleum ether. Natural polymers are economical, biodegradable and can be chemically modified. Different ratios of drug and guggul resin were tried in the formulation of sustained release matrix tablets of tolterodine tartrate. Wet granulation technique was adopted for preparation of tolterodine tartrate granules, showed good flow properties and compressibility. The fabricated tablets were evaluated for various physicochemical characteristics and in vitro release studies like hardness, thickness, weight variation, friability, drug content and content uniformity were found to be within the limits. The drug release of optimized formulation $\left(\mathrm{F}_{6}\right)$ was fitted to various kinetic models and the $\mathrm{R}^{2}$ value is 0.988 and the $\mathrm{n}$ value of drug release is 0.787 . Therefore, the drug release follows zero order with non-fickian diffusion. The mechanism of drug release involves erosion and diffusion. Stability studies were performed for the optimized formulation as per ICH guidelines climatic zone III and were found to be stable with insignificant changes in physicochemical characteristics and in vitro release studies.
\end{abstract}

Key words: Preparation, Evaluation, Matrix, Gluggul resin

\section{Introduction}

The oral route administration is mostly adopted route because of its comfortable dosage form design and patient care. The term sustained release is used to achieve or extend therapeutic effect by continuously releasing medication over an extended period of time after administration of a dose (Janizen and Robinson, 1995). Matrix system is widely used for the purpose of sustained release. It is the release system which prolongs and controls the release of the drug that is dissolved or dispersed. In fact, a matrix is defined as a well-mixed composite of one or more drugs with gelling agent i.e. hydrophilic polymers (Salsa et al., 1997).

Several parameters should be kept in mind before formulating sustained release dosage form which includes various $\mathrm{pH}$ in GIT, the gastrointestinal motility, the effect on the dosage form and the drug. Most of sustained release dosage forms follow the mechanism of diffusion, dissolution or combination of both, to produce slow release of drug at predetermined rate.

Guggul is the oleogumresin of Commiphora mukul, a plant that is native to India, and its extracts include compounds known for their hypolipidemic properties the Z- and $\mathrm{E}$ - isomers of guggul sterone and its related guggul sterols. Guggul resin has been used as inactive pharmaceutical ingredients like binding agent and rate retarding polymer. Therapeutic uses of guggul include treatment of nervous diseases, leprosy, muscle spasms, ophthalmia, skin disorders, ulcerative pharyngitis, hypertension, ischaemia and urinary disorder.

Correspondence to: K. Latha; E-mail: lathakukatil@gmail.com 
Guggul extract contains $5 \%$ to $10 \%$ guggul sterone, Indian pharmacopeia (IP) recommends maximum guggul sterone concentration in supplements of $4 \%$ to $6 \%$ and it has to be taken in an amount equivalent to $25 \mathrm{mg}$ guggul sterones three times a day. Information about one of its clinical trials stated $400 \mathrm{mg}$ guggul extract is equivalent to 25 mg guggul sterone dose, which would be $6.25 \%$ guggul sterones, in clinical trial the effectively treated dose was $1200 \mathrm{mg}$ guggul sterones daily.

\section{Materials and Methods}

Tolterodine tartrate is gift sample from Hetero Drugs Pvt. Ltd., Hyderabad, Telangana, India. Guggul gum purchased from Nuzen labs, PVP K-30 purchased from Burgoyne Burbidge \& co., Potassium dihydrogen phosphate, sodium hydroxide, Isopropyl alcohol, Talc, Magnesium stearate purchased from SD fine chemicals.

\section{Experimental Methodology}

Extraction of resin from guggul: Crude guggul was finely powdered with the help of mortar and pestle. The powdered guggul (200 g) was extracted repeatedly with $500 \mathrm{ml}$ ether for 4 times. Filtrates were combined and concentrated to dryness at $40{ }^{\circ} \mathrm{C}$ to get pure resin. The percentage yield of the resin was calculated in terms of air dried weight of drug and found to be $100 \mathrm{mg}$. the dried mass was milled and passed through \# 120. It is stored in the desiccator for further use (Bharath et al., 2012).

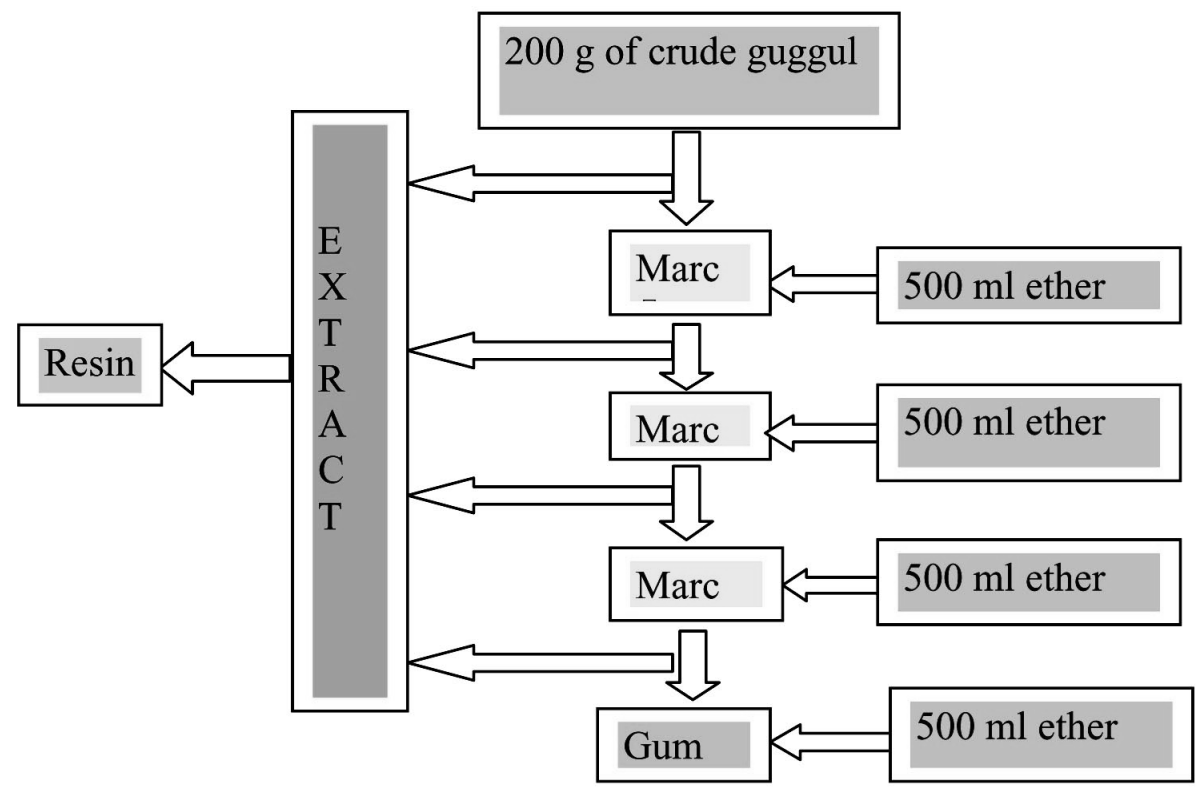

Figure 1. Flow chart representing extraction of resin.

\section{Evaluation of guggul resin}

Solubility studies: The solubility of extracted guggul resin was performed in various solvents like water, methanol, ethanol, acetone, chloroform etc. (Scott, 2005).

Melting point: The melting point of the guggul resin was determined with the help of melting point determination apparatus (Scott, 2005).
Salkowski test: Guggul resin was dissolved in chloroform and it was treated with few drops of acetic anhydride and then added with concentrated sulphuric acid (Scott, 2005).

Determination of total ash: About $3 \mathrm{~g}$ of dried guggul resin powder material was accurately weighed and taken into a previously ignited and tarred crucible. The evenly spread as a fine layer and ignited gradually by increasing the temperature to 
$500-600^{\circ} \mathrm{C}$ until it was colorless indicating the absence of carbon. The crucible was cooled in desiccator and weighed. The procedure was repeated to get constant weight. The percentage of total ash was calculated with reference to air dried material (Idian Pharmacopoeia, 2010).

Determination of sulphated ash: About $3 \mathrm{~g}$ of guggul resin accurately weighed and taken in a silica crucible, ignited until the substance was thoroughly charred, cooled. Moisten the residue with $1 \mathrm{ml}$ of sulphuric acid then ignited as before and further allowed to cool and weighed. The process was repeated until constant weight (Idian Pharmacopoeia, 2010).

Determination of percentage loss on drying: About $1 \mathrm{~g}$ of guggul resin was accurately weighed and the sample was placed in oven for $1 \mathrm{hr}$ at $55-65^{\circ} \mathrm{C}$. The percentage loss on drying was calculated with the formula (Idian Pharmacopoeia, 2010).

$\% \mathrm{LOD}=$ initial weight- final weight/initial weight

\section{Preformulation studies}

Preformulation testing is an investigation of physical and chemical properties of a drug substance alone and when combined with excipients. It is the first step in the rational development of dosage forms.

Fourier Transform Infra Red (FTIR): The drug and excipient compatibility studies were studied by FTIR spectrum analysis. FTIR spectra were recorded (using a Shimadzu Corporation (Koyto, Japan)). Test sample was prepared by mixing few mg of sample with potassium bromide and compacting at 10 tons pressure. The resultant disc was mounted in a suitable holder in IR spectrophotometer and the IR spectrum was recorded from $4000 \mathrm{~cm}^{-1}$ to $500 \mathrm{~cm}^{-1}$. The resultant spectrum was compared for any spectral changes (Raghavendra et al., 2009; Chandan and Salika, 2013).

Precompression parameters of powder blends: Required quantity of each ingredient was taken for each specified formulation and all the ingredients were subjected to grinding to a required degree of fineness then passed through sieve No. 60. Granules were prepared by blending powder PVP K 30 in IPA solution as granulating agent and the wet mass was screened using sieve No. 44 . The dried granules and powder blends were dried and subjected to pre compression tests (Kwabena et al., 2010; Jigar et al., 2011).

Angle of repose: Angle of repose is the maximum angle possible between the surface pile of granules and horizontal plane. The frictional forces in the granules can be measured by angle of repose. The tangent of angle of repose is equal to the co-efficient friction $(\mu)$ between the particles. Hence the rougher and more irregular the surface of particles, the greater will be angle of repose (Idian Pharmacopoeia, 2010)

Fixed amount of blend was accurately taken and carefully poured through the funnel whose tip was secured at a height of $2.5 \mathrm{~cm}$ above the graph paper which is placed on a horizontal surface. The blend was poured until the apex of the conical pile just touches the tip of the funnel. The interrelationship between the angle of repose and flow properties of powder are shown in the Angle of repose is calculated by the following formula.

$$
\theta=\operatorname{Tan}^{-1}(\mathrm{~h} / \mathrm{r})
$$

Where, $\theta=$ angle of repose, $\mathrm{r}=$ radius of the pile, $\mathrm{h}=$ height of the pile.

Bulk density: Defined as the mass of a powder divided by the bulk volume. It is the ratio of the mass of an untapped powder sample and its volume including the contribution of inter particulate void volume. Hence, the bulk density depends on both the density of powder particles and the spatial arrangement of particles in the powder bed (Idian Pharmacopoeia, 2010)

Apparent bulk density $(* \mathrm{~b})$ was determined by pouring the blend into a graduated cylinder. The bulk volume $\left(\mathrm{V}^{*}\right)$ and weight of the powder $(\mathrm{M})$ was determined. The bulk density was calculated using the formula.

$$
* \mathrm{~b}=\mathrm{M} / \mathrm{V} *
$$

Tapped density: The tapped density is obtained by mechanically tapping a graduated measuring cylinder or vessel containing the powder sample. After observing the initial powder volume or mass, 
the measuring cylinder or vessel is mechanically tapped and volume or mass readings are taken until little further volume or mass change is observed. The mechanical tapping is achieved by raising the cylinder or vessel and allowing it to drop, under its own mass (Idian Pharmacopoeia, 2010)

The measuring cylinder containing a known mass of blend was tapped for a fixed time (around 100). The minimum volume $\left(\mathrm{V}_{\mathrm{t}}\right)$ occupied in the cylinder and the weight (M) of the blend was measured. The tapped density $(* t)$ was calculated using the formula,

$$
* \mathrm{t}=\mathrm{M} / \mathrm{V}
$$

Carr's index: Is an indication of the compressibility of a powder. It is an indirect measure of bulk density, size and shape, surface area, moisture content and cohesiveness of materials, because all of these influence the observed compressibility index (Idian Pharmacopoeia, 2010). The correlation between compressibility index and powder flow properties is given in the Table 1

The simplest way for measurement of free flow of powder is compressibility, an indication of the ease with which a material can be induced to flow is given by compressibility index (C.I) which is calculated using the formula,

$$
\begin{array}{r}
\text { CI (\%) = Tapped Density (TD) - Bulk } \\
\text { density (BD) / Tapped Density (TD) X } 100
\end{array}
$$

Hausner's ratio: Is an indirect index of ease of powder flow ${ }^{[10]}$. The correlation between Hausner's ratio and the flow properties of powder are given in the Table 1.

It was calculated by using the formula,

$$
\text { Hausner's ratio }=* \mathrm{t} / * \mathrm{~d}
$$

Where $*$ t=tapped density, $* \mathrm{~d}=$ bulk density

\section{Preparation of tablets}

The drug tolterodine tartrate and the polymer guggul resin are passed through the sieve No. 60 . Drug was geometrically mixed with polymer until a homogeneous blend was obtained. Granules were prepared using 5\% w/v PVP K30 in 1:1 hydro alcoholic mixture then passed through sieve No. 44 for wet screening. Granules were dried at $60{ }^{\circ} \mathrm{C}$ for 1 $\mathrm{hr}$ and passed through sieve No. 30 for dry screening. Magnesium stearate and talc were used at $1 \%$. Final blend was compressed in to tablets with a 10 station rotary tablet machine (Rimek, Ahmadabad) using 4 $\mathrm{mm}$ punch. Total weight of the tablet is $50 \pm 0.05$ mg.

Table 1. Formulations of sustained release tablets of Tolterodine tartrate.

\begin{tabular}{lcccccc}
\hline \multirow{2}{*}{ Ingredients (mg) } & \multicolumn{7}{c}{ Formulations of different ratios of drug and resin } \\
\cline { 2 - 6 } & TTG1 & TTG2 & TTG3 & TTG4 & TTG5 & TTG6 \\
Tolterodine tartrate & $(1: 2)$ & $(1: 4)$ & $(1: 6)$ & $(1: 8)$ & $(1: 9)$ & $(1: 10)$ \\
Guggul & 4 & 4 & 4 & 4 & 4 & 4 \\
MCC & 8 & 16 & 24 & 32 & 36 & 40 \\
Mg stearate & 37 & 29 & 21 & 17 & 9 & 7 \\
Talc & 0.5 & 0.5 & 0.5 & 0.5 & 0.5 & 0.5 \\
Weight of individual tablet & 0.5 & 0.5 & 0.5 & 0.5 & 0.5 & 0.5 \\
\hline
\end{tabular}

Note: $5 \%$ of PVP K30 is used as binder, TTG - Tolterodine tartrate and guggul.

Evaluation of prepared tablets (Dinanath et al., 2011)

Tablet thickness: The thickness in millimeters (mm) was measured individually for 10 pre weighed tablets by using screw gauge (Mitutyo Japan). The average thickness and standard deviation were reported. 
Tablet hardness: Tablet hardness was measured using Monsanto hardness tester. The crushing strength of the 10 tablets with known weight and thickness of each was reported.

Friability test: From each batch, ten tablets were accurately weighed and placed in the Friability test apparatus (Roche Friabilator). Apparatus was operated at $25 \mathrm{rpm}$ for 4 minutes and tablets were observed while rotating. The tablets were then taken after 100 rotations, dedusted and reweighed. Friability values below $1 \%$ are generally acceptable.

$\%$ Friability $=\left(\mathrm{W}_{1}-\mathrm{W}_{2}\right) \times 100 / \mathrm{W}_{1}$

Where, $\mathrm{W}_{1}=$ Initial weight of the 20 tablets

$\mathrm{W}_{2}=$ Final weight of the 20 tablets after testing.

Weight variation test: To study weight variation individual weights $\left(\mathrm{W}_{\mathrm{I}}\right)$ of twenty tablets from each formulation were noted using electronic balance. Their average weight $\left(\mathrm{W}_{\mathrm{A}}\right)$ was calculated. Percent weight variation was calculated as follows.

$\%$ weight variation $=\left(\mathrm{W}_{\mathrm{A}}-\mathrm{W}_{\mathrm{I}}\right) \times 100 / \mathrm{W}_{\mathrm{A}}$

Drug content: The drug content of the tablets meets the requirements if the amount of the active ingredient in each of the 10 tested tablets lies within the range of $90 \%$ to $110 \%$ of the standard amount. About10 tablets were weighed and taken into a mortar and crushed into fine powder. An accurately weighed portion of the powder equivalent to about $100 \mathrm{mg}$ of drug (tolterodine tartrate) was transferred to a $100 \mathrm{ml}$ volumetric flask containing $\mathrm{pH} 6.8$ phosphate buffer. It was shaken by mechanical means for 1hour.Then it was filtered through whatman filter paper. From this resulted solution $1 \mathrm{ml}$ was taken, diluted to $10 \mathrm{ml}$ with $\mathrm{pH} 6.8$ phosphate buffer and absorbance was measured against blank at $281 \mathrm{~nm}$ for tolterodine tartrate tablets.

Content uniformity: Randomly select 30 tablets. Among which 10 were assayed individually. The Tablet pass the test if 9 of the 10 tablets must contain not less than $85 \%$ and not more than $115 \%$ of the labeled drug content and the $10^{\text {th }}$ tablet may not contain less than $75 \%$ and more than $125 \%$ of the labeled content. If these conditions are not met, remaining 20 tablets assayed individually and none may fall outside of the 85 to $115 \%$ range.
Dissolution study of tablets: The tablet was placed in vessel of dissolution test apparatus USP II (paddle) containing $900 \mathrm{ml}$ of $\mathrm{pH} 6.8$ phosphate buffer rotating at $100 \mathrm{rpm}$. Aliquot of $5 \mathrm{ml}$ was withdrawn for every $1 \mathrm{hr}$ up to $12 \mathrm{hrs}$ and replaced with $5 \mathrm{ml}$ of fresh $\mathrm{pH} 6.8$ phosphate buffer. Each sample was analyzed at $281 \mathrm{~nm}$ using double beam UV and visible spectrophotometer against blank. The release studies were conducted in triplicate and the mean values were plotted versus time and drug concentration was calculated using standard calibration curve.

\section{Kinetic analysis of dissolution data (Model dependent kinetics)}

To analyze the in vitro release data various kinetic models were used to describe the release kinetics. The zero order rate equation describes the systems where the drug release rate is independent of its concentration. In this graph is plotted between cumulative \% drug release vs. time (Zero order kinetic model). The first order Equation describes the release from system where release rate is concentration dependent. In this graph is plotted between $\log$ cumulative of $\%$ drug remaining vs. time (First order kinetic model). Higuchi (1963) described the release of drugs from insoluble matrix as a square root of time dependent process based on Fickian diffusion Equation. In this graph is plotted between cumulative $\%$ drug release vs. square root of time (Higuchi model). Korsmeyer et al., (1983) derived a simple relationship which described drug release from a polymeric system. To find out the mechanism of drug release, drug release data was fitted in Korsmeyer Peppas model. The $\mathrm{n}$ value is used to characterize different release mechanisms. A plot of $\log$ cumulative $\%$ drug release vs. $\log$ time was made.

Accelerated stability studies: The optimized formulation was subjected to stability studies at $40{ }^{\circ} \mathrm{C}$ $\pm 2{ }^{\circ} \mathrm{C} / 75 \% \pm 5 \% \mathrm{RH}$ for period of one month ${ }^{[13]}$. Each tablet was individually wrapped in aluminum foil and packed in amber colored bottle and put at above specified condition in a humidity chamber for one month. At the regular time intervals tablets were 
analyzed for the hardness, disintegration time, drug content and in vitro drug release.

\section{Results and Discussion}

\section{Evaluation of guggul resin}

Solubility studies: Resin showed good solubility in petroleum ether and chloroform and found practically insoluble in ethanol, methanol, acetone and water.

Melting point: The melting point of the guggul resin was found to be around $95-100^{\circ} \mathrm{C}$.

Salkowski test: The formation of reddish brown color in the lower layer indicating the presence of sterols.

Determination of total ash: The percentage of total ash was calculated with reference to air dried material and it was found to be $11.6 \%$.

Determination of sulphated ash: The percentage of sulphated ash was calculated with reference to air dried material and it was found to be $13.2 \%$.

Determination of percentage loss on drying: The percentage of loss on drying was found to be $0.13 \%$.

Table 2. Evaluation of Guggul resin.

\begin{tabular}{ll}
\hline Parameters & Guggul resin \\
\hline Description & Fine powder \\
Color & Pale yellowish brown \\
Odour & Pleasant \\
Taste & Bitter \\
Solubility & $\begin{array}{l}\text { Soluble in petroleum ether and } \\
\text { chloroform }\end{array}$ \\
Melting point & $95-100^{\circ} \mathrm{C}$ \\
Salkowski test & $\begin{array}{l}\text { Formation of reddish brown color } \\
\text { in lower layer }\end{array}$ \\
Loss on drying & $0.13 \%$ \\
Total ash & $11.6 \%$ \\
Sulphated ash & $13.2 \%$ \\
\hline
\end{tabular}

Based on results obtained in Table 2 guggul is soluble in petroleum ether and chloroform, Salkowski test indicated the presents of sterols, total ash, sulphated ash and loss on drying indicate the sample is pure.

\section{Preformulation studies}

Drug-excipients compatibility study by FTIR: Compatibility between tolterodine tartrate and guggul resin was studied by FTIR.

From the above IR spectra (Figure 2a-c) the peaks representing the pure drugs $3571.92 \mathrm{O}-\mathrm{H}$ stretch Alcohol, phenols.1701.10 $\mathrm{C}=\mathrm{O}$ stretch, Carboxylic acid.1488.94 N-O asymmetric stretch, Nitro compound 1427.23 C-C stretch (in ring), Aromatic 1249.79 C=O stretch Alcohol, carboxylic acid, esters and ethers were similar in all the graphs suggesting that there are no interactions and the pure drugs were not altered functionally.

Based on results obtained from Table 3, Precompression parameters of the entire power blend were conducted for angle of repose, bulk density, compressibility index, hausner's ratio. Values for angle of repose were found in the range of $32.43 \pm$ 0.08 to $38.43 \pm 0.12$ (I.P limits $25-30$ ) showing that the blend of power has poor flow. The value for Carr's index was in between $11.19 \pm 17$ to $69 \pm 0.03$ (I.P limit 11-15) indicating that all batches of powder blend has poor compressibility. Hausner's ratio were found in the range of $1.11 \pm 0.06$ to1.22 \pm 0.04 (I.P limits 1.12-1.18). The results showed that powder blend has poor flow.

\section{Evaluation of flow properties}

It was found that tolterodine tartrate do not possess the required flow characteristics for direct compression. Hence tablets were prepared by using.wet.granulation method.

Based on results obtained from the Angle of repose of the granules was in the range $28.49 \pm 0.08$ to $31.29 \pm 0.04$ showing that the granules were free flowing. The Carr's index was in between $8.75 \pm 0.04$ to $11.15 \pm 0.04$ indicating that all the batches of granules were having good compressibility. Hausner's ratio was to be in the range $1.03 \pm 0.09$ to $1.12 \pm 0.06$. The results showed that all the formulations were in good blend properties. 


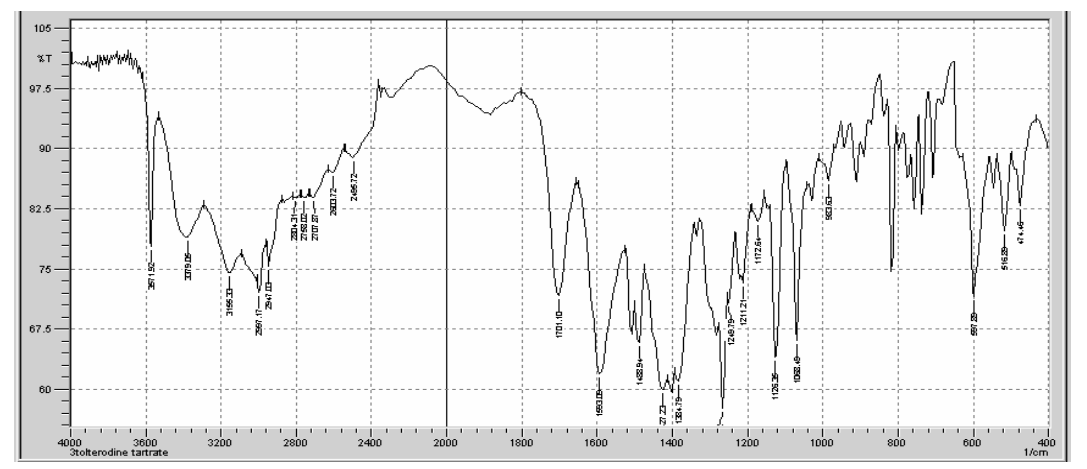

Figure 2a. FTIR of Tolterodine tartrate.

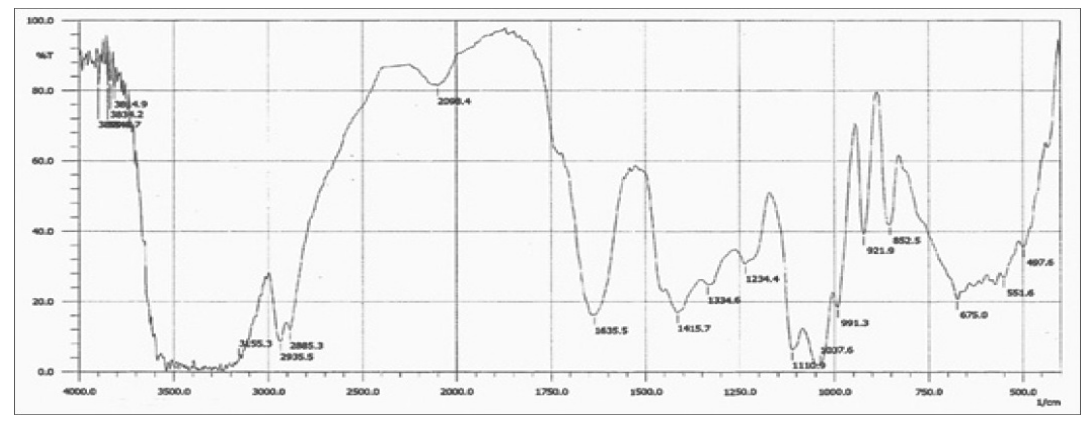

Figure 2b. FTIR of Guggul resin.

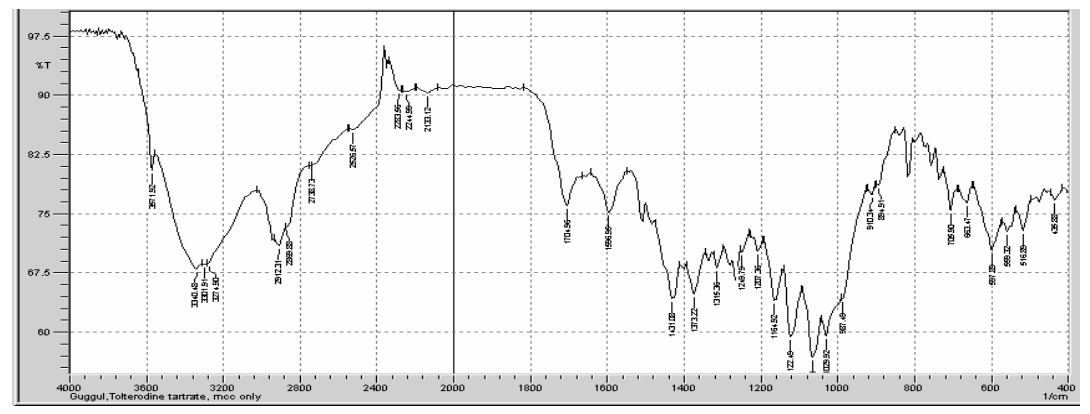

Figure 2c. FTIR of Tolterodine tartrate and guggul resin.

Table 3. Preformulation parameters of the pure drug and guggul resin powder.

\begin{tabular}{lccccc}
\hline Code & $\begin{array}{c}\text { Bulk } \\
\text { density }\end{array}$ & $\begin{array}{c}\text { Tapped } \\
\text { Density }\end{array}$ & $\begin{array}{c}\text { Angle of } \\
\text { Repose }\end{array}$ & $\begin{array}{c}\text { Carr's } \\
\text { index }\end{array}$ & $\begin{array}{c}\text { Hausner's } \\
\text { Ratio }\end{array}$ \\
\hline Drug & $0.25 \pm 0.03$ & $0.39 \pm 0.12$ & $35.63 \pm 0.13$ & $16.43 \pm 0.24$ & $1.13 \pm 0.05$ \\
TTGP1 & $0.36 \pm 0.02$ & $0.39 \pm 0.05$ & $37.17 \pm 0.08$ & $17.15 \pm 0.04$ & $1.22 \pm 0.04$ \\
TTGP2 & $0.39 \pm 0.06$ & $0.46 \pm 0.05$ & $36.29 \pm 0.08$ & $15.75 \pm 0.04$ & $1.12 \pm 0.06$ \\
TTGP3 & $0.31 \pm 0.06$ & $0.35 \pm 0.02$ & $38.43 \pm 0.12$ & $11.12 \pm 0.07$ & $1.15 \pm 0.04$ \\
TTGP4 & $0.39 \pm 0.02$ & $0.45 \pm 0.06$ & $35.30 \pm 0.09$ & $17.69 \pm 0.03$ & $1.11 \pm 0.06$ \\
TTGP5 & $0.46 \pm 0.04$ & $0.52 \pm 0.05$ & $32.43 \pm 0.08$ & $16.51 \pm 0.31$ & $1.14 \pm 0.09$ \\
TTGP6 & $0.49 \pm 0.05$ & $0.56 \pm 0.03$ & $37.51 \pm 0.12$ & $14.63 \pm 0.05$ & $1.20 \pm 0.09$ \\
\hline
\end{tabular}

Values are expressed as Mean $\pm \mathrm{SD}, \mathrm{n}=3$. 
Table 4. Pre formulation parameters of granules.

\begin{tabular}{lccccc}
\hline Code & Bulk density & $\begin{array}{c}\text { Tapped } \\
\text { density }\end{array}$ & $\begin{array}{c}\text { Angle } \\
\text { of repose }\end{array}$ & $\begin{array}{c}\text { Carr's } \\
\text { Index }\end{array}$ & $\begin{array}{c}\text { Hausner's } \\
\text { Ratio }\end{array}$ \\
\hline TTG1 & $0.36 \pm 0.01$ & $0.39 \pm 0.03$ & $29.17 \pm 0.06$ & $11.15 \pm 0.04$ & $1.10 \pm 0.04$ \\
TTG2 & $0.39 \pm 0.05$ & $0.42 \pm 0.02$ & $31.29 \pm 0.04$ & $8.75 \pm 0.04$ & $1.12 \pm 0.06$ \\
TTG3 & $0.31 \pm 0.03$ & $0.35 \pm 0.01$ & $30.61 \pm 0.03$ & $9.12 \pm 0.07$ & $1.08 \pm 0.04$ \\
TTG4 & $0.39 \pm 0.01$ & $0.45 \pm 0.08$ & $30.29 \pm 0.02$ & $7.69 \pm 0.03$ & $1.11 \pm 0.006$ \\
TTG5 & $0.46 \pm 0.04$ & $0.52 \pm 0.06$ & $28.49 \pm 0.08$ & $10.51 \pm 0.31$ & $1.07 \pm 0.09$ \\
TTG6 & $0.49 \pm 0.05$ & $0.56 \pm 0.05$ & $31.15 \pm 0.03$ & $8.63 \pm 0.05$ & $1.03 \pm 0.09$ \\
\hline
\end{tabular}

Values are expressed as Mean $\pm \mathrm{SD}, \mathrm{n}=3$.

\section{Evaluation of tablets}

From evaluation of prepared matrix tablets Table 5 , the hardness of tolterodine tartarate sustained release tablets was found to be in the range of $5.5 \pm 0.32$ to $5.7 \pm 0$, thickness of the tablets $2.2 \pm 0.15$ to $2.6 \pm 0.09$, weight variation in the range of $46.9 \pm 0.58$ to $49.13 \pm 0.6$, friability $0.32 \pm 0.09$ to $0.37 \pm 0.02$, drug content $98.2 \pm 0.64$ to $99.7 \pm 0.15$ and content uniformity $97.2 \pm 0.78$ to $99.0 \pm 0.12$. This indicated that the evaluation parameters for all the formulations

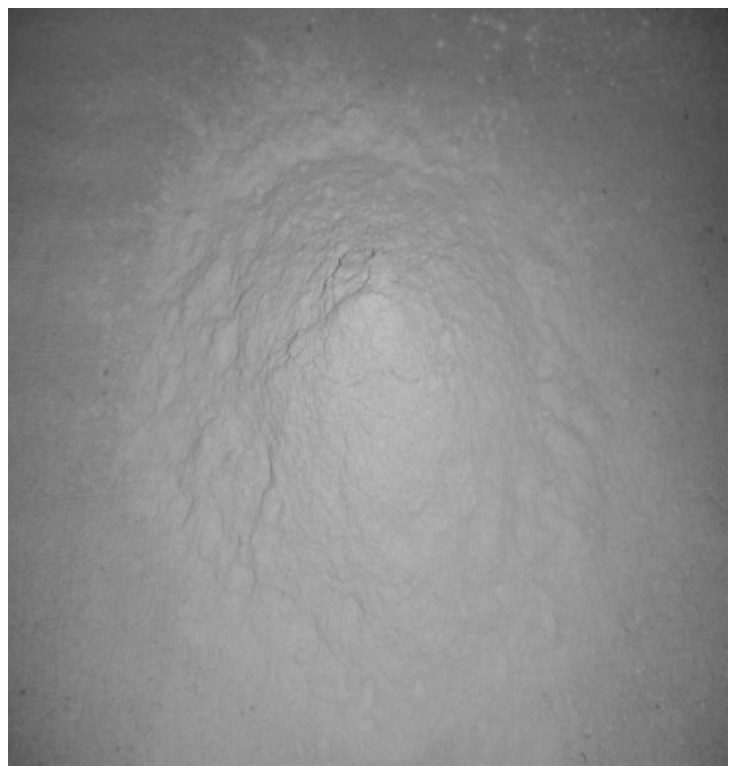

(a) were within the limits. The prepared matrix tablets showed in Figure 3.

Based on results obtained from Figure 4, among all the formulations of sustain release matrix tablets, formulation TTG6 1:10 ratio of tolterodine tartrate : guggul resin showed $97.5 \pm 0.42$ release in $12 \mathrm{hrs}$ was optimized $^{[14]}$.

Drug release kinetics: Model dependent drug release profiles of all the formulations were placed into zero order release model, first order release model, Higuchi model and Korsmeyer-Peppas model.

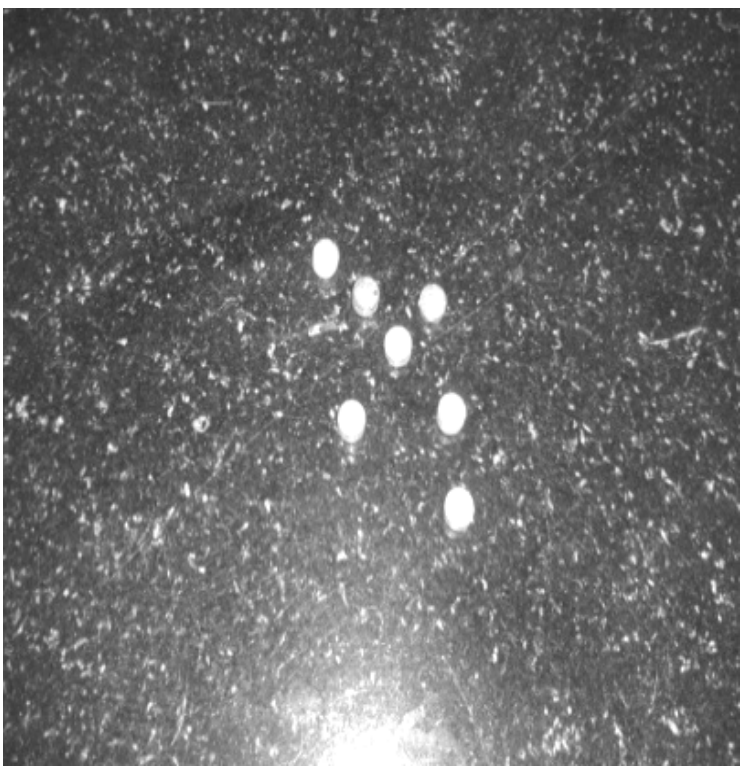

(b)

Figure 3. Picture representing (a) guggul resin (b) prepared tablets using guggul resin. 
Table 5. Physiochemical evaluations of tolterodine tartrate matrix tablets.

\begin{tabular}{ccccccc}
\hline Code & $\begin{array}{c}\text { Hardness }^{\mathrm{a}} \\
\left(\mathrm{kg} / \mathrm{cm}^{2}\right)\end{array}$ & $\begin{array}{c}\text { Thickness }^{\mathrm{b}} \\
(\mathrm{mm})\end{array}$ & $\begin{array}{c}\text { Weight } \\
\text { Variation } \\
(\%)\end{array}$ & $\begin{array}{c}\text { Friability }^{\mathrm{d}} \\
(\%)\end{array}$ & $\begin{array}{c}\text { Drug content } \\
(\%)\end{array}$ & $\begin{array}{c}{ }^{\mathrm{C}} \\
\text { Content }^{\mathrm{fniformity}} \\
(\mathrm{mg})\end{array}$ \\
\hline TTG1 & $5.5 \pm 0.32$ & $2.3 \pm 0.19$ & $46.9 \pm 0.58$ & $0.37 \pm 0.02$ & $98.2 \pm 1.09$ & $97.9 \pm 0.86$ \\
TTG2 & $5.7 \pm 0.20$ & $2.4 \pm 0.15$ & $48.2 \pm 0.52$ & $0.36 \pm 0.29$ & $97.9 \pm 0.54$ & $98.2 \pm 0.78$ \\
TTG3 & $5.6 \pm 0.15$ & $2.3 \pm 0.20$ & $47.1 \pm 0.6$ & $0.34 \pm 0.12$ & $98.2 \pm 0.64$ & $98.7 \pm 0.53$ \\
TTG4 & $5.5 \pm 0.32$ & $2.4 \pm 0.15$ & $48.93 \pm 0.5$ & $0.34 \pm 0.07$ & $99.2 \pm 0.80$ & $97.2 \pm 0.78$ \\
TTG5 & $5.6 \pm 0.29$ & $2.6 \pm 0.09$ & $48.50 \pm 0.4$ & $0.32 \pm 0.09$ & $98.4 \pm 0.64$ & $99.0 \pm 0.12$ \\
TTG6 & $5.7 \pm 0.178$ & $2.2 \pm 0.15$ & $49.13 \pm 0.6$ & $0.33 \pm 0.02$ & $99.7 \pm 0.15$ & $98.3 \pm 0.19$ \\
\hline
\end{tabular}

Note: Values are expressed as Mean \pm SD for a \& b: $n=5$, c: $n=20$, d, e and f: $n=10$.

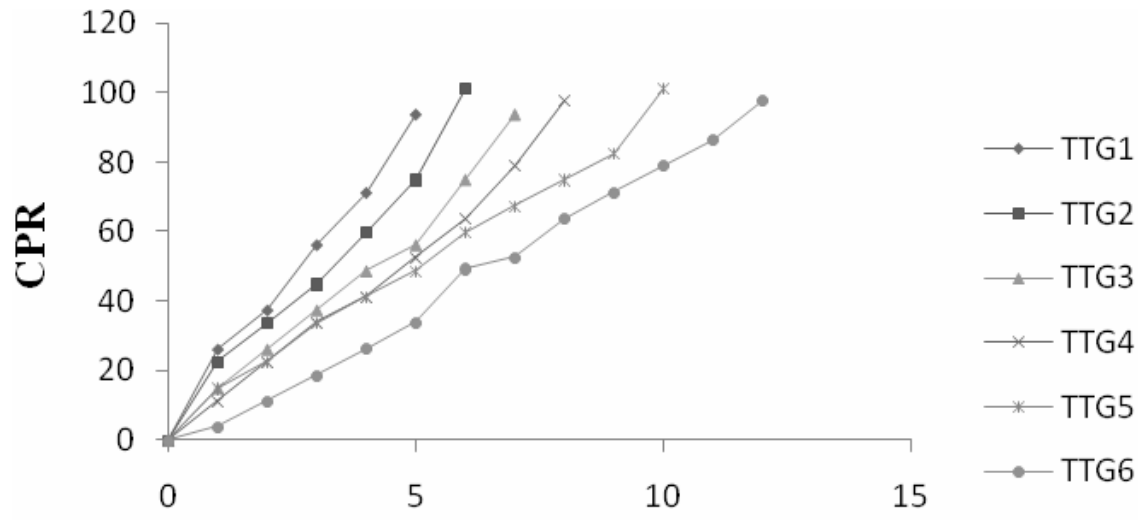

Time (Hrs)

Figure 4. Dissolution profiles of the prepared formulations.

Table 6. Model dependent kinetic analysis for different formulations.

\begin{tabular}{ccccccl}
\hline \multirow{2}{*}{ CODE } & $\begin{array}{c}\text { Zero } \\
\text { order }\end{array}$ & $\begin{array}{c}\text { First } \\
\text { Order }\end{array}$ & Higuchi & \multicolumn{2}{c}{$\begin{array}{c}\text { Korsmeyer- } \\
\text { Peppas }\end{array}$} & \multirow{2}{*}{ Release Mechanism } \\
\cline { 2 - 5 } & $\mathrm{R}^{2}$ & $\mathrm{R}^{2}$ & $\mathrm{R}^{2}$ & $\mathrm{R}^{2}$ & $\mathrm{n}$ & \\
\hline TTG1 & 0.988 & 0.989 & 0.955 & 0.974 & 0.787 & Non fickian diffusion \\
TTG2 & 0.973 & 0.992 & 0.916 & 0.968 & 0.813 & Non fickian diffusion \\
TTG3 & 0.902 & 0.962 & 0.992 & 0.989 & 0.911 & SupercaseII transport \\
TTG4 & 0.985 & 0.941 & 0.949 & 0.994 & 1.002 & SupercaseII transport \\
TTG5 & 0.995 & 0.932 & 0.971 & 0.987 & 0.870 & Non fickian diffusion \\
TTG6 & 0.997 & 0.862 & 0.963 & 0.996 & 0.778 & Non fickian diffusion \\
\hline
\end{tabular}

Based on in vitro drug release of different formulations given in Figure 4 the formulation $F_{6}$ showed maximum release of drug for more than $12 \mathrm{~h}$. The drug release from optimized formulation $\left(\mathrm{F}_{6}\right)$ was fitted to various kinetic models as given in Table
6 and the $R^{2}$ value is 0.988 and the $n$ value of drug release is 0.787 . Therefore the drug release follows zero order with Non-fickian diffusion release mechanism. 
Stability studies: Optimized formulation was subjected for stability studies for one month and the physiochemical evaluations of optimized tolterodine tartrate matrix tablets were performed.

Based on the results shown in Table 7 and Figure 5 , it can be concluded that optimized tablets were stable during accelerated stability studies, with insignificant change in the hardness, thickness, weight variation, friability, drug content and in vitro drug release characteristics.

Table 7. Physicochemical Evaluations of optimized formulation during stability studies.

\begin{tabular}{ccccccc}
\hline Duration & $\begin{array}{c}\text { Hardness } \\
\left(\mathrm{kg} / \mathrm{cm}^{2}\right)\end{array}$ & $\begin{array}{c}\text { Thickness } \\
(\mathrm{mm})\end{array}$ & $\begin{array}{c}\text { Weight } \\
\text { Variation }(\%)\end{array}$ & $\begin{array}{c}\text { Friability } \\
(\%)\end{array}$ & $\begin{array}{c}\text { Drug } \\
\text { content } \\
(\%)\end{array}$ & $\begin{array}{c}\text { Content } \\
\text { uniformity } \\
(\mathrm{mg})\end{array}$ \\
\hline 0 week & $6.18 \pm 0.26$ & $2.23 \pm 0.30$ & $49.6 \pm 0.22$ & $0.33 \pm 0.22$ & $99.5 \pm 0.54$ & $99.3 \pm 0.92$ \\
$1^{\text {st }}$ week & $5.59 \pm 0.35$ & $2.15 \pm 0.51$ & $47.9 \pm 0.44$ & $0.34 \pm 0.18$ & $98.7 \pm 0.90$ & $98.5 \pm 0.73$ \\
$2^{\text {nd }}$ week & $5.76 \pm 0.23$ & $2.08 \pm 0.86$ & $48.9 \pm 0.44$ & $0.32 \pm 0,02$ & $101.2 \pm 0.3$ & $98.9 \pm 0.64$ \\
1 month & $5.80 \pm 0.25$ & $2.23 \pm 0.21$ & $49.0 \pm 0.60$ & $0.33 \pm 0.17$ & $99.5 \pm 0.42$ & $99.2 \pm 0.12$ \\
\hline
\end{tabular}

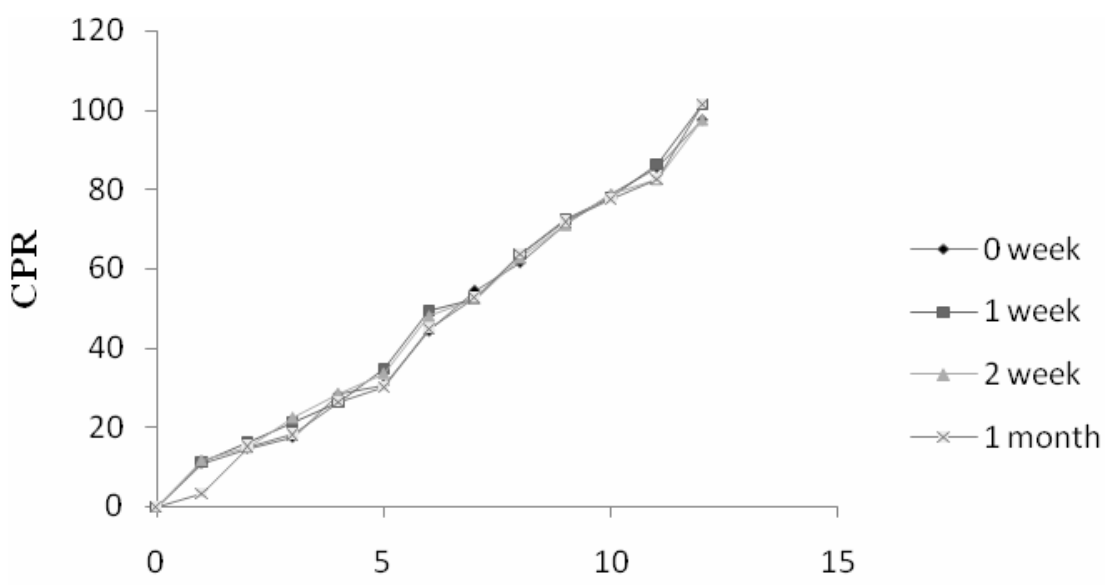

Time (Hrs)

Figure 5. Percentage drug release of optimized formulation during ASS.

\section{Conclusions}

Different ratios of drug and guggul resin were tried in the formulation of sustain release matrix tablets of tolterodine tartrate. Wet granulation technique was adopted which showed good flow properties and compressibility. Formulation $\mathrm{F}_{6}$ showed maximum release of drug for more than $12 \mathrm{~h}$ with the $\mathrm{R}^{2}$ value was 0.988 and the $\mathrm{n}$ value of drug release was 0.787 . Therefore, the drug release follow zero order with non-fickian diffusion and the mechanism of drug release was erosion and diffusion. Stability studies were performed for the optimised formulation as per ICH guidelines climatic zone III and were found to be stable. The matrix tablets prepared with guggul resin can be used to sustained the release of tolterodine tartrate.

\section{References}

Bharath, S., Venkatesh Teja, B., Deveswaran, R., Basavaraj, B.V. and Madhavan, V. 2012. Modified multiple emulsion technique for the microencapsulation of Diclofenac Sodium using olibanum resin as a polymer. Int. J. of Pharm. and Chemical Sci. 1, 508-515. 
Chandan, Garg. and Vikrant, Saluja. 2013. Once-daily sustained-release matrix tablets of metformin hydrochloride based on an enteric polymer and chitosan. J. Pharm. Education and Res. 4, 92-97.

Dinanath, Gaikwad, Jadhav, R.T., Amol Limkar, Sangeeta S., Kisan Bobe. and Manoj Patil. 2011. Formulation and Evaluation of Sustained Release Tablet of Aceclofenac by Film Coating. Inte. J. of Res. in Pharm. and Biomedical Sci. 2, pp. 310-318.

Indian Pharmacopeia 2010, published by Indian Pharmacopeia Commission, Ghaziabad Volume 2, 751-754.

Indian pharmacopoeia. 2010. Govt. of India, ministry of health and family welfare, The Indian pharmacopoeia commission, Ghaziabad, pp. 82 -193.

Jantzen, G.M. and Robinson, J.R. 1995. Sustained and Controlled- Release Drug Delivery systems. Modern Pharmaceutics. 121, 501-502.

Jigar Patel, A., Jitendra Patel, S., Arjun Sony and Hemangi Patel J. 2011. Formulation and evaluation of immediate release tablet of azithromycin by dry granulation method using super disintegrants. American J. of Pharm. Tech. Res. 1, 211-218.
Kwabena, Ofori-Kwakye, Frederic, Osei-Yeboah and Samuel, Lugrie Kipo. 2010. Formulation and quality evaluation of two conventional release tablet formulations. Int. J. of Pharm. Sci. Rev. and Res. 4, 94-99.

Raghavendra, Rao. V.G., Gandhi Sagar. and Patel, Tarun., 2009. Formulation and evaluation of sustained release matrix tablets of tramadol hydrochloride. Int. J. of Pharm. and Pharm. Sci. 1, 60-70.

Salsa, T., Veiga, F. and Pina. M.E. 1997. Oral controlled release dosage form I. Cellulose ether polymers in hydrophilic matrices. Drug Develop. Indian Pharm. 23, 929-938.

Scott Masten, A. 2005. Gum Guggul and Some of Its Steroidal Constituents.ntp.niehs.nih.gov/ntp/htdocs/ chem_background/.../gumguggul_508.pp. 1-39. 